\title{
Cultural contradictions of post-Fordism in the context of the transformation of European peripheries through the prism of the class of subcontractors
}

Keywords: transformation, post-Fordism, class of subcontractors, lean management

\begin{abstract}
The presented paper deals with the basic issues, dilemmas and social and cultural contradictions in the Polish transformation process against the background of Central and Eastern Europe, the processes of the establishment and development of new states and nations as well as the new markets. The author views these problems through the light of the emergence of a broad class of subcontractors in a turbulent environment and the new modes of production, which are a result of changes in the structure of human labour introduced by post-Fordism (in its final stage, lean management) and postmodernity. The author also analyzes the social change as a consequence of social relations resulting from exchanging the life chances of the actors for the class-conditioned market opportunities in the existing social and political situation (conjoncture) and at the present stage of transformation at the moment when the emergent markets get shaped and mature. The study makes use of the hermeneutic method, which is finding out the essence of the present phase of transformation through the light of new concepts against the background of the historical-comparative analysis. The present article is not aimed at ordering reality but it is an inspiration for studies and for approaching transformation in accordance with a new conceptual apparatus of social sciences, sociology, management and political economy.
\end{abstract}

* ORCID ID: https://orcid.org/0000-0003-0993-2173; Ph.D., sociologist, Faculty of Engineering Management Białystok University of Technology. Email: w.poplawski@pb.edu.pl 


\section{Post-Fordism and peripherality - characteristics of the transformation process}

The way to regulate the social and economic situation in the period of transformation after 1989 was the system of a peripheral capitalism state. That was a period of rapid changes, turbulences and hardships for the societies of post-communist Europe. The early years of transformation in Poland were filled with ideological slogans of social market economy, which people understood rather naively as a "lyrical model of capitalism". That model, which in post-communism was expected to make up for all the shortcomings that state socialism (even in Gierek's decade) did not manage to create through "state capitalism without a state" ${ }^{\text {, was }}$ seen as a romantic model of "taking one's life and matters in one's own hands", which means a specifically understood life resourcefulness ${ }^{2}$. The idea of reaching the West European model of social market economy in the process of transformation was easier to accept socially for a number of reasons. Sometimes it was seen as national independence from Russia (or Serbia in the area of former Yugoslavian countries), and sometimes as idealization of individual entrepreneurship. Mainly, however, it appeared as a devotion necessary for a better future, especially as increasing consumptive opportunities of the new generations. Strong rationalization of transformation into capitalism was seen as an inevitable phase of development after the grey mediocrity and poverty of real socialism.

Bankruptcy of the real socialist state was perceived in the collective consciousness of its citizens as a lack of trust in the state generally. This phenomenon was manifested in Poland on a large scale in the form of contestation of state institutions, especially the ideological and repression apparatus after the huge movement of "Solidarity" was suppressed. None of the important social actors: large industrial and traditional working class, the working intelligentsia (including its broadest group - officials), individual farmers or even small owners had no illusions as to whether the state worked and was able to face the challenges of the huge change. Social defeatism (so characteristic for Poland in the sad decade of Jaruzelski, Romania in the times of Ceausescu or Yugoslavia "orphaned" by Josip Broz-Tito) changed into cultural optimism (in

1 Gf. M. Dahl, Niemiecki model społecznej gospodarki rynkowej jako wzór dla polskich przemian systemowych po 1989 roku, Warszawa 2015, pp. 301-314; J. Staniszkis, Postkomunizm. Próba opisu, Gdańsk 2005, pp. 153-190.

2 T. Popławski, Peryferyjność i społeczeństwo. Dylematy przełomu w Europie, Białystok 1997, pp. 91-110. 
Poland - already after minister Wilczek's reform which liberalized the economy in 1988, and next in the period of so-called Balcerowicz's plan), which changed economy and provided it with a new impulse. Central Eastern economies appeared as emerging markets and real socialism was replaced by liberalism. It created a space of freedom unquestioned by anyone and undermined not only the principle of equality but also social justice earlier viewed as egalitarianism of the needs, which was reflected in the slogan "everybody has the same stomach". Liberalism also created nomenclature forms which without any obstacles exploited the collapsed states by "wild privatization" of state property and the oligarchy established on this basis. The class of owners of the captured property which grew into the financial oligarchy became the pillar and the main actor of peripheral capitalism in this part of the world. To describe this phenomenon, Zbigniew Galor used the concept of lumpen property ${ }^{3}$.

Post-socialist societies and states coped with this process differently and co-created it in different ways. Surprisingly, it was such societies as the Polish one, which had completely stopped believing that the state could help them on the way to welfare and that they could count on it in any way, that generally coped the best. The country's bankruptcy after a decade of Jaruzelski's government, political chaos, strikes and hyperinflation deepened the social feelings of distrust towards the authorities. The idea of a protective state seemed then distant and hard to realize. This despair became the basis for the citizens' faith in their own strength and in the future shaped with their own hands and minds. The future seemed rather like a stage of devotion whose aim was to make it better for the generations to come. The myth of the West European lower middle class consumptionism seduced to such an extent that huge class sections were neglected and marginalized. It was just assumed that they were only the "sawdust" of the process of historical transformation, as it would be said by Krzywicki in his essay Idea a życie ${ }^{4}$. A striking example was complete marginalization of a big class of agricultural workers of State Agricultural Farms or traditional workers of local industry in smaller urban centers. Fascination with consumptionism covered all social problems (like, for example, high unemployment), which nearly $1 / 5$ of the society struggled with and which showed that not everybody "joined the journey to... a consumption paradise" . It can be said that

3 Z. Galor, Bezrobocie a lumpenwtasność, [in:] J. Tittenbrun (ed.), Własność i interesy $w$ dobie transformacji, Poznań 2006, pp. 285-322.

4 L. Krzywicki, Idea a życie. Z wczesnej publicystyki (1883-1892), Warszawa 1957.

5 M. Dahl, ibid., p. 315. 
considerably bigger fractions of the society decided selfishly that they were more predisposed than others and they climbed the social ladder on the shoulders of those for whom they left only as much as was necessary to survive and not to think about a revolutionary way of claiming social justice. In simple words: not to think about the difficult way in which they were passed by through the contestation of the new reality or an open social rebellion whose emanation was Lepper bottom-up social movement "Self-defence".

\section{Towards stabilization of peripheral capitalism - the emergence of a class of subcontractors}

It seems that the conceptual apparatus popular with Polish wellknown sociologists in the 1990's such as Jerzy Szacki, Joanna Kurczewska, or Stanisław Kozyr-Kowalski and connected with the concept of "civic society" has little power to explain and it mostly serves as an ideological cover. It usually makes use of some variety of a theory of social and cultural imitation. In an optimistic version - Polish sociology is inspired by Gabriel Tarde's or Stefan Czarnowski's theories of cultural diffusion, while in a pessimistic one it is inspired by Max Weber's results of works. The first one emphasizes that imitation is a creative adaptation, or just diffusion of innovations from the first to the second world. The other, pessimistic one, says that not all societies but hardly any have such a cultural potential in their religions that capitalism could be created (e.g. compared to other denominations, Puritans and Protestants distinguish themselves in this respect). The others will create some kind of peripheral capitalism. Creative adaptation is not synonymous to the feeling of satisfaction with the reality, which is characteristic of the centers, but it frequently means that one can work hard to survive or even to achieve what seemed to have been given once and for all in the previous system. The world's ideas are usually driven by the idea of "the golden age" but this "golden age" is completely different for different societies. In the world centers, the "golden age" of society is usually identified with its contemporary times, which are improved by means of democratic and market mechanisms. "The golden age", therefore, means vivacité of capitalism, its vitality, which contains in itself controlling the ceaseless social change. It is no surprise then that it translates into human activities and it drives them in a variety of ways. In the post-Ricardian, Marxist or Paretian political economy we call this phenomenon effective- 
ness, which is well pictured by Pareto in the example of the ruling class or speculators. Let us remember that in Ricardo's economy effective activities are an effect of specialization, which is characterized by the system of work in one country and whose effects can be exchanged for the work of economic actors in another country. The comparative costs of this exchange will usually be advantageous for both sides, its effectiveness will be greater and the consumer will receive a better product than if there were no possibilities of effectiveness, especially of international exchange. The market is becoming richer and consumption more diversified. Specialization gives birth to process. What about those who have nothing to exchange and who drop out of the chain of exchange about whom Ricardo says nothing about? Marx's voice that they will make a revolution to take away from the owners is not taken into consideration now since the historical reason - as claimed by a French Heglist Jacques d'Hondt, whose lecturers I participated in, when he compared the "old, wise Hegel" and the "hot-headed Marx" - was on the side of those "patient economists", and not on the side of the "hot-headed" revolutionaries.

A huge change is, however, not only a creative adaptation but also the activity of people who are afraid of it, they do not want it or even cannot imagine the reality after the change... or even people who are not fit for reality. They often seem to be outside the main current, somewhere on the periphery of capitalism. The effect of them not joining in, restraining from activity or counter-acting can be treated but as passive resistance. The new reality is unknown so it is almost always frightening and worse because of being uncertain. This fear is a significant part of the transformational social reality.

Let us now refer to a well-known Weberian concept and let us say emphatically that although the new reality makes them participate in the market, even assigning roles for them, these are usually secondary roles and this does not ensure for them realization of life opportunities as market chances. Life is tailored to fit the possibilities, which means that it creates market opportunities or excludes their existence. Then we remain outside the market, on its periphery. There are few market opportunities for the actors of the social change on the market of peripheral capitalism. For example, this is the situation of the employees of the state-owned sector (workers of large industry and office workers) and the cooperative sector (especially socialized agriculture) whose occupational opportunities got considerably smaller at the beginning of transformation. They were marginalized or even excluded. Thus in the period of 
transformation the road to welfare for a lot of main social actors was de facto closed. Only a much larger expenditure of labour as compared to the previous system secures the possibility for their families to survive. Democracy without welfare disappoints, especially the citizens of those countries where nomenclature was replaced by oligarchy. In their common consciousness this state is perceived as social injustice but also as maneuvering to avoid duties, which wastes developmental opportunities and a chance for a better life. Once I called this state meandering development but now I would probably give it a much stronger name, namely developmental jugglery ${ }^{6}$. This manner of functioning can be seen in an almost pure form in Lukashenko's Belarus and not only there but also, for example, in the rest of the post-Soviet area or on a considerable part of the Balkan area. It leads to oligarchization of economic life and domination of the political nomenclature using the state's property and their political position to get rich on this property. Then it is difficult to build the so-called middle class ${ }^{7}$ unless it is established on the basis of foreign capital. Then managers of such enterprises manage the workers in industry, logistics, transport or the staff of, for instance, points of sale. These investments lead to the growth of the upper layer of the workers' classes, workers of trade or services and, as a consequence of this process - to the employment of the working force in the economic units of subcontractors of big firms and large world brands. Central Europe mostly works for the German industry and its brands and their main function from Germany's perspective is to reduce the costs of labour ${ }^{8}$. It is not only Foreign Direct Investment (FDI) which creates the class of subcontractors but also the dictate of chain stores and trade conquered by discount stores and wholesale trade change free farmers and gardeners into a class dependent on the final producer who lowers (or, to put it in a more picturesque way, "squeezes") prices and causes dependence due to the privileged position in the chain of supplies to the market. Lowering the prices for supplies for the producers, low margins of profit, delaying the dates of payment for the goods (i.e. de facto, enforcing the so-called trade credits on them), dependence on the banks with foreign capital,

6 T. Popławski (ed.), Oblicza peryferyjności. Polska, Québec (Kanada), Biatoruś, Białystok 1994, pp. 10-14.

7 H. Domański, Polska klasa średnia, Wrocław 2002.

8 K. Popławski, Rola Europy Środkowej w gospodarce Niemiec, Warszawa 2016; T.G. Grosse, Tragedia państw peryferyjnych, czyli o geopolitycznych dylematach Polski w Unii Europejskiej, [in:] T. Zarycki (ed.), Polska jako peryferie, Warszawa 2016, pp. 39-41; M. Dahl, Niemiecki model spotecznej gospodarki rynkowej..., pp. 301-316. 
impossibility of getting credit for one's own business (while individual consumption is gladly encouraged) - this was the policy supported by the governments of pro-Western liberals and ideologically imposed on the sovereign (people) by means of the media and the symbolic violence of the state's apparatuses. Their role is discussed in the classical work by Althusser9. Guy Bajoit states that although "thousands of workers incorporate the class habitus (in the sense attributed by Bourdieu T.P.) through socialization, this does not mean that they are all engaged in the same logic of collective activities (movements)"10. Associations and cooperatives of small firms, especially in trade and peri-agricultural sectors started to be used as forms of defense. This was accomplished on a high level, in my opinion, only by the Polish dairy industry.

Almost the only way to ensure that these actors will survive after privatization is - except the satisfaction of the domestic demand - involvement in the global market system though realization of subsupplies. The logic of domination - subordination also becomes the logic of stabilization on a low level within transformational peripherality of those emerging markets. In other words, the class of subcontractors appears on a large scale and it is characterized by the following features: - dependence on external firms and brands, which integrate and impose their own system of work, establishing their branches or supplying orders,

- they function in the system of work established within FDI and sometimes work in the companies appropriated during the liberal phase of privatization (frequently referred to as "wild"),

- a wide range of occupations (including new ones) dependent on demand from abroad - from specialized physical (industry of precision mechanics, production of car parts) and traditional ones to physical-mental ones (in peri-agricultural industries, trade, services, logistics) or even in accountancy, law, audit, marketing or IT,

- low wages (even 3-4 times lower) for the workers in analogous posts in parent companies in the countries of their headquarters or brands,

- dependence, availability and organizational subordination,

- uncertain class situation and a low bargaining power (they can be replaced or eliminated from the market following the policy of the central office, e.g. French car concerns or telecommunications companies),

9 L. Althusser, Ideologia i ideologiczne aparaty państwa, Warszawa 1983.

10 G. Bajoit, Le changement social, Paris 2003, p. 133. 
- a low share in the profit (dividends and profits are divided by the central headquarters),

- worse status of occupations and jobs which are a result of the process of internalization or conditions of sub-supplies, e.g. place in the distribution system.

The following part of the present article discusses the basic relation between the class of subcontractors and post-Fordism in the phase of lean management, which produces them and bases upon them.

The classes of subcontractors accepted their situation of European second-class workers (from second-class countries, too) since they created neither strong trade unions nor other forms of counteracting marginalization. They were kept in the state of subordination through the uncertainty concerning what would happen to them when the capital changed localization and moved to the country of even lower labour costs (e.g. for many years Fiat threatened to move from Tychy to Kragujevac in Serbia and it was not until December 2020 that they announced the production of new models in spite of the fact that the factory in Poland was considered the best in the whole FCA group). This uncertainty legitimized both a much worse situation of workers or farmers in Central Europe, reflected in low wages, and the limitation of certain EU regulations which were unfavourable for them (the famous Posting of Workers directive pushed through by the president of France Macron which limited the competitiveness of mainly Polish transport firms). It is said that capital (allegedly!) does not have nationality but is ruled by the law of profit. Until now it has not been understood that although "A Cossack caught a Tartar, the Tartar also grabs his head"11, as a Polish saying goes. In other words, the peripheral subcontractor also has the bargaining power. Transferring the production (and, as a consequence, workplaces) back to the countries providing the capital with nationality, that is central and parent ones, would mean bankruptcy of a lot of firms and brands due to increased costs. A positive effect of their expansion was, however, keeping the work places in peripheral countries of subcontractors, even at the cost of employees from the dominant country, where the capital comes from. In simple words, if the German firms employed subcontractors, for example for its car industry in Germany and not in the Visegrad countries, the rates for labour would increase 4-5 times. As a consequence, Germany, as the "dominator" in the export of the

11 A line from a poem for children by a Polish poet Julian Tuwim "Rycerz Krzykalski". It means that though somebody tries to trick another person, they are at the same time tricked by the latter. 
world car industry, could drop out of the market considering the fact that their products are already overpriced today in relation to the value for money, which is still maintained as rational, mainly thanks to the class of subcontractors from the Czech Republic, that is the employees and the staffs from the Škoda Works or from Hungary in case of the Audi Works. The foundation of success was the market and subcontractors from China. Toyota uses the method of vertical integration of subcontractors, which means that Polish suppliers of gearboxes are trained only to follow the standards of Toyota and it would be hard for them to come onto the free market or in another system. Sheer exploitation concerned small producers, subcontractors or, in particular, producers from very poor countries such as, for example, Bangladesh, where the wages were very low while labour was decisively cheaper. Even the protests by ecologists and consumers did not improve the situation of subcontractors from those countries, whereas the cultural acceptance of the lower position in post-communist countries was related to the long-strengthened complex in relation to the West.

\section{Economic mentality of the class of subcontractors and their system of values in the context of the post-Fordist order based on labour}

Post-Fordism as a form of capitalism has gone through different stages of development since the times of automatization and robotization but the most important is the last one, connected with lean management. Capitalistic vitality acquires a new quality in the context of the organization of the process of the assembly line work through effectiveness on the one hand, while on the other, as a relation of domination/subordination. An important theory of lean management itself was presented by Bowman and Faulkner ${ }^{12}$. The history of human labour does not know a system of work more effective than post-Fordism. In Poland, the concept of post-Fordism appeared in the context of the report from the trilateral commission - government, employers and employees - by Juliusz Gardawski and his team ${ }^{13}$. It was also referred to by other researchers from the Institute of Public Affairs (e.g. Jerzy Hausner) in their reports and collective works on the social system of

12 D. Faulkner, C. Bowman, Strategie konkurencji, Warszawa 1996, pp. 35-49.

13 J. Gardawski, Zwiazki zawodowe na rozdrożu, Warszawa 2001, pp. 44-52. 
work in Poland at the beginning of the system transformation. It can be said that this term was in this way deprived of the heuristic potential. Such a concept of post-Fordism was deprived of effectiveness connected with the revolution of managers and with innovativeness. The latter was attributed to older theories by Joseph Schumpeter or Daniel Bell with his analysis of post-industrial society, or the process of travail en miettes by Georges Friedmann (and Pierre Naville'a) with their analysis of the role of transforming traditional workers into specialized ones in the process of the assembly line, monotonous and Fordist work (OT ouvrièrs qualifiés traditionnels / OS ouvrièrs specialisés $)^{14}$. Lean management appears later and it is transformed into an "ideological cover" organizing the system of world labour in post-Fordist capitalism, i.e. its last stage. Limiting the costs in the form of lean management becomes an element of competitive advantage and a way to gain a decent profit from the basic activity of the enterprise equaling the fair profit. It was Alain Lipietz, in his nearly genius and certainly far-reaching speech on "fault ideas and open questions about post-Fordism" at the conference in Lake Arrowhead in 1991, who defined - in my opinion, doing it very aptly - the essence of the concept of post-Fordism, also showing what toyotism as the last known stage of post-Fordism means. It was analyzed in an interesting manner by Pierre W. Boudreault in his book about power and enterprise in the post-industrial region on the example of the cultural capital of Quebec entrepreneurs who - according to him, on the basis of their own cultural capital in the sense attached to it by Bourdieu ${ }^{15} \mathrm{a}-$ fought an unequal struggle with American corporations ${ }^{16}$. Some sociologists and economists believed that changes in the process of work were obvious and moved on to analyze globalization according to Stiglitz, Bauman's postmodernity in the form of "liquid reality" or "network societies" according to Castells. They glossed over post-Fordism (even in the phase of lean management) and started to deal with information and network society. Others focused on the role of services, thinking that in the contemporary world the problem is not production but services and computerization. The present situation of the shock caused by the Coronavirus epidemic triggered a short discussion on transferring the chain of supplies, e.g. for the German car concerns from China (if only from

\footnotetext{
14 G. Friedmann, Le Travail en miettes, Paris 1964; R. Sainsaulieu, Lidentité du travail, Paris 1977; N. Poulantzas, Les classes sociales dans le capitalisme aujourd'hui, Paris 1974, pp. 28-284.

15 P.W. Boudreault, Du pouvoir et de l'entreprise dans une région post-industrielle. Le capital culturel et la ruse dans la création d'emploi, Chicoutimi 1994, pp. 237-243.

16 Ibidem, pp. 36-51.
} 
Shenzhen or Wuhan) to the specific Visegrad (or Serbia or Romanian) "g-locality" without enforcing their establishment so far from the final producers ${ }^{17}$. It seems that the recently opened convertibility of the yuan into other currencies may cause such an effect but as long as its rate is considerably underestimated, when the system has been shaken by the pandemic, sub-supplies will return to China anyway. We remember well the manifold underestimation of labour in Poland before 1989 (the conversion rate of \$). It is likely that it is the Chinese subcontractors and their brands will dictate the conditions to German or French concerns by buying out the famous brands (like, recently, Volvo) and introducing their own (e.g. Geely, Polestar or electrical BYD), in a similar way as it did with Xiaomi or Huawei (so much fought against by the West) or it is doing now with Oppo, Vivo, OnePlus, Haier, and even with AliExpress and Alibaba. The Chinese monopoly in lean management shook the possibilities of other countries going by way of establishing the classes of subcontractors from the periphery to the capitalist developmental core. Chinese subcontractors were not only cheap but they also offered to international concerns the internal market which is the largest in the world and which is growing at a fast pace. The present limitation is the possibility that Chinese brands will take over the suppliers and this possibility is strengthened by the new Chinese policy basing not on the labour force from the demographic reserve, which finished in 2010, but on a certain kind of "inbreeding", which is building the internal demand and affluence of the inhabitants (through the strategy of Chinese companies). In other words, why should subcontractors look for foreign corporations if they can adopt intellectual property, learn the ways of production, take over and integrate subcontractors and build their own corporations? Vietnam, the Philippines, Indonesia or the Visegrad group countries keep pace by creating a specific elite of post-Fordist suppliers. The "catchalls": lean managements, production transfer, assembly, world product, delocalization, outsourcing, subcontracting were used and repeated but absolutely unthinkingly. The mind of capitalist concerns (i.e. their greed) caused the drifting of states and even powers ${ }^{18}$. This was the way to understand the electoral program of the USA president

17 Poland set for a nearshoring boom?, https://eurobuildcee.com/en/news/30040-poland-set-for-anearshoring-boom (29.01.2021).

18 T. Popławski, Dylematy zbiorowej świadomości w obliczu „dryfowania” peryferyjnego państw. Esej o zmianie społecznej w państwach transformacyjnych, [in:] Z. Galor, R. Miński, P. Sałustowicz (eds.), Afirmacja czy kontestacja? Dylemat społeczeństwa kapitalistycznego w kryzysie, Bielefeld 2014, pp. 245-260. 
Donald Trump which was based on the idea of the production returning to its nursery (i.e. the American province), or the governments of Italy (in case of FCA group) or France (in case of PSA and Renault) fighting against transferring car production to the countries of East Europe. On the other hand, however, the success of cheap brands such as Renaultdependent Dacia base on much lower costs of labour and supplies. The situation is similar in agricultural and food production or in road transport and logistics.

The countries of subcontractors already function on the world level in the process of transformation of human labour. It can be said that Poland and Europe have managed to get hold of capitalism; nevertheless, they are late at least by one stage, by one link in the chain of production, or in the chain of values for the customer. During the pandemic the process of delocalization got questioned; however, it is not the producers or firms of subcontractors which are increasing their bargaining force in the existing situation but it is just the firms of the dominant countries which are doing so. These firms and their employees now resemble a citizen fighting for a place in a queue in the epoch of socialism. The cleverer one won and finally even the winner got nothing despite the efforts. It happened because the economy collapsed or the dominators changed the rules of the game. It was them who the establishment of those rules depended on. "Localize the subcontractor closer to the main producer" - is the postCovid recommendation now. A sufficiently emphatic example are simply incredible efforts and resourcefulness of the inhabitants of Poland, which can be described as "the country of eternal transformation". Its population acquired a lot of abilities and cunning to adapt to the changing, turbulent conditions. They are poorly rewarded for this and they are left behind, fulfilling the increasingly newer requirements. I described this attitude elsewhere as an attitude of "resourcefulness which gives birth to entrepreneurship" ${ }^{19}$. It is hardly possible not to acknowledge that lean management was applied here in relation to the whole population of the country as a method of exploitation, which resembles the rule of plucking a hen in such a way that its feathers could still regrow. Slimming down the production process, bankruptcy of firms, involvement in the chain of subcontractors, privileges for the capital coming in at the cost of no privileges for one's own entrepreneurs, exploitation of labour and workers, a supply of the educated and high quality workforce for free through brain drain and migrations, the system of education to the ben-

19 T. Popławski, Peryferyjność $i$ spoteczeństwo..., chapters V and IX. 
efit of the dominator country, permanent reduction of costs, outsourcing, subcontracting, reforms of schooling, cheap medical treatment, automatization - is it not a specific lean management? In addition, high quality work and products for a low price and a low payment - is it not worth the reward? The reward does exist but this effort is not compensated for by the possibilities of a decent life. The profit of the leading firms is not usually decent since it generally bases on an underpaid workforce (in the Third Republic of Poland). The situation is similar with the underpaid workers who were "slimmed down of their wages" by this lean management, so dangerous for the periphery.

The wise authorities are learning not to give away the most precious resources. And the most precious resource are the social actors, now valuable already in the international dimension while not so long ago (in the state socialism) they constituted a value for the state or - at the very most - for the local markets, which means the closed markets of national states. Therefore, this "Copernican revolution", which was consumption without ownership (by installments, before the consumer achieved some savings) was not completely carried out in the interest of the dependent state's citizens. It happened most frequently that it made them - as the class of subcontractors - considerably dependent not only on the firms but on commercial banks as well. Due to the low wages, those banks took part in the reproduction of consumption opportunities and the level of life of the families of those workers, especially in the sectors which made themselves dependent on foreign investors. Hence this gap between the consumption opportunities in large cities' central offices and in the province (Poland A and Poland B).

I already noticed in the early 1990's that transformation was based on changing life resourcefulness into entrepreneurship, and hardly anybody sees that it is increasingly often changed into creativity, along with its most spread form of creative imitation, which is the foundation of innovativeness ${ }^{20}$. Post-communism seems to be a naïve neoliberalism whose application sucks out not only the firms belonging to the state (so-called "national silver") from the population of transformation countries. Innovativeness cannot be learnt and this large scale "slimming” of people of enterprising imitative countries becomes not only the social fact but it also considerably multiplies economic losses. It also "slims" the country of the chance to get out of the woods (ruin of

20 T. Popławski (ed.), Oblicza peryferyjności..., pp. 51-76; T. Popławski, Peryferyjność i społeczeństwo..., p. 167. 
the retirement system, inventiveness for foreigners, exogenous development, shaken generation bonds, population crisis). In the book about a vision of fair globalization which brought him the Nobel the guru of the world economy Joseph E. Stiglitz, in the sub-chapter entitled "Countries in the process of departing from communism"21, where he criticizes too fast reforms, especially the economic ones, which are unadjusted to the specific character of those countries, writes about disbelief in the development of these countries. As I emphasized earlier, without implementing the post-Fordist modes of production it is impossible to produce a product which would be at the same time better, faster, newer (more innovative) and cheaper. Here post-Fordism is combined with lean management and classes of subcontractors. It suffices to compare the hourly rate for work in Switzerland or in Germany to the payment for the same activities within the working hours in Poland or in China, not mentioning Bangladesh. China or India have one more advantage, which I emphasize very strongly on the basis of my intuition based on work abroad in the period of state socialism, that they can create the so-called convertibility rate on the basis of unexchangeable currency. This rate usually considerably lowers the country's rate in relation to the rate for the same work abroad. Hence, it constitutes the basis for delocalization and outsourcing, those "holy Grails" of contemporary management. Bowman and Faulkner explain it superbly in a different way in their concept of ensuring the value where they reveal the mysterious essence of the process of lean management. This essence first of all includes constant cost reduction (CCR), then - benefits from the scale and range of activity ( $\mathrm{S}+\mathrm{R}$, where I would also add standardization), and next lowering the costs of production factors (CPF, comprising energy cost) and the advantages from control and coordination $(\mathrm{C}+\mathrm{C}$, especially on the world level in the production of the so-called global product) - which constitute the basis of system competitiveness. The other three factors, on the other hand, are the elements of operation competitiveness. Firstly, innovativeness (I), raising the value for the customer (RV) and ensuring the value $(\mathrm{EV})$, which assumes that despite the profit on production costs the value for the customer at least does not decrease ${ }^{22}$. I must add a few things besides the role of the "exchangeability rate" of the value of work in different countries. At present post-Fordism determines the strength and vitality of capitalism. It even introduces a so far unknown

21 J. Stiglitz, Wizja sprawiedliwej globalizacji. Propozycje usprawnien, Warszawa 2007, pp. 56-59.

22 D. Faulkner, C. Bowman, Strategie konkurencji, Warszawa 1996, pp. 35-49. 
concept - moral wear of a product, a very clear example of which are cellular networks replacing smartphones with more modern, better, cheaper and faster ones. There is no time for modification of products, their restyling or face lifting during the life cycle on the market. The large domestic market, which especially in case of China (but also India or Indonesia) gives possibilities of the creation of brands and only then their internalization. It becomes for them an advantage, creating the so-called effect of production scale and the brand strength. Examples of Chinese brands can be given here, like Xiaomi, Huawei, Alibaba, Geely, TCL, Imperial, Goodride, Oppo, Vivo, Haier, Hisense and others which were earlier unknown and which now make the world top. A question arises whether what Japan and Germany (after the war destruction) and later South Korea succeeded in thanks to the American aid will also make success in China. In these cases the scale is incomparable. They certainly did manage to transform the class of hardworking peasants into the class of subcontractors and then the class of specialized workers. At the same time the length of the phases leading to the creation of the class of large industry workers got reduced. The existence of this class and the ideological domination in the states was gladly justified, produced and destroyed by the state socialism as a petty system of production deprived of any historical vitality. Alexander Lukashenko's regime in Belarus has attempted till now to lengthen the functioning of such a class system. Other countries, such as Uzbekistan or Kazakhstan, witness dictatorship and even a "clan and family" oligarchization of economies.

\section{The state of meandering development and peripheral capitalism - conclusions}

A discussion on development rarely concerns a peripheral country. It usually refers to the so-called Tiger States, European or Asian, and only the countries considered to be those "tigers" change. Neither does it concern the ways out of this peripherality or the ways of coping with this situation. The weaknesses that keep such a state drifting can become the reason to submit it to the domination of those which are stronger in the military (e.g. Belarus within the Union State of Russia and Belarus), demographic or other respects, though sometimes less organized and developed (e.g. Russia). Weak countries have problems with this and they drift, torn with the internal and external "dialectics" of dependencies, like it can be clearly seen in Ukraine or Georgia. 
The turbulent environment favours such situations since it additionally weakens the drifting state which is trying to remain at the end of the chain of capitalist labour. This touches even those who think that they have made up for the distance but they only belong to the aforementioned group of subcontractors in relation to the post-Fordist-oriented systems of domination. Peripheral capitalism does not provide surpluses but it enforces burning out of the reserves and reaching for their deeper layers. The surplus on the value of the product from subcontractors is very small as compared to the branded dominator on the market from the leading country, which is frequently a world concern that in fact rules the market by managing the chain of subcontractors and - consequently - shaking the economies of peripheral countries in the chain of post-Fordist states.

The dependence is still increased by the expansion of huge transnational sales networks which pressurize the subcontractors by creating cheap network brands. The subcontractor from a peripheral country hardly has anything to say since their bargaining power in negotiations is negligible. This is shown by the situation of the Polish franchise networks like Lewiatan, Marcpol, or Chorten, composed of small shops, which noticed it too late but they managed to remain on the market despite the expansion of Lidl, Auchan or Carrefour. Protests from consumer and ecological organizations in big European countries even recommended boycotting the brands (e.g. of clothes industry) which do not control the scale of exploitation of the workers from the class of subcontractors from the peripheral countries of the world ${ }^{23}$. Greed drives motivation to exploit and it is a self-driving motif of enterprising activities. The reaction of equally greedy criminal groups are copycats which create places of work in peripheral countries but they spoil the market and the reputation of brands. A similar situation takes place in case of computer programs and games as well as music pieces and films. Copying and downloading increases the availability of those products. Customers (or even countries which tolerate this) "take revenge" in this specific manner on concerns for raising the prices excessively, even sometimes at the cost of the authors because such a practice considerably lowers the availability of a given piece. According to OECD, as much as 3.3\% of the world trade may be the turnover with faked products.

23 Consumers protest against starvation wages in clothes industry, https://m.ekonsument.pl/a66746 konsumenci_protestuja_przeciwko_glodowym_placom_wnbspprzemysle_odziezowym.html $(30.01 .2021)$. 
Imitative development is one of developmental strategies of whole states and it means permission for imitation, and even copying, but with simultaneous control and development of their own innovative potential at all costs and with the marker closed for those who produce original products and outpace those countries regarding development. Similar examples can be multiplied in the face of the expansion of post-Fordism and its effects for subcontractors and the comprador form of making countries dependent on transnational concerns in the context of their domination even over the weaker and smaller countries. An increasing role of banks and enormous financial institutions together with the importance of mass media (i.e. the most powerful firms from the Silicon Valley and from Hollywood) basing on information and communication technologies, mainly connected with the Internet and the growing role of the so-called creative industry, fills up the picture after the war lost by the class of subcontractors and their state. It was the war where their chances were negligible. Virtual communities constitute specific information-communication hubs. In the case of the Polish class of subcontractors, which includes unusually hard working farmers and gardeners, two strategies can be seen. One is the strategy of sucking out applied towards the local intermediaries, wholesalers and networks, especially of discount stores, while the other is sucking out the workforce from Poland to work in the leading agricultural countries such as Germany or the Netherlands, and even Italy. It can be added that even military powers, such as Russia in case of Nord Stream 2, are trying to get the privileged position of a subcontractor-dominator, which will be hard in the context of the so-called diversification of gas markets, which de facto is a losing competition with the American gas in the form of $\mathrm{LNG}^{24}$.

Post-Fordism is manifested in the periphery in the creation of a network of subcontractors whose bargaining power in the chain of values for the consumers on the leading markers is small. It depends on their importance to the central offices which take care about the stability of international brands coming from those countries. The possibilities of creating one's own identity or brands is limited by the lack of domestic capital, problems with acquiring international capital and by the consumers themselves who are convinced of the superiority of products from abroad or who identify them poorly. The fact that the advantages of buying domestic products are not embedded in social consciousness places

24 LNG contracted by Poland's PGNiG 20-30\% cheaper than Russian gas -minister, https://www. reuters.com/article/poland-gas-russia-idUSL5N25X1LG (30.01.2021). 
producers in a difficult situation in the context of poor recognizability of Polish brands. Consumer patriotism does not help in fighting with wealthier enterprises from the West for the creation of one's own specializations followed by the achievement of high margins of profit. The few actions supporting it (e.g. the emblem Teraz Polska ${ }^{25}$ ) are toned down by the medial superiority and the test which prove the superiority of foreign products over the Polish ones. A product from abroad ousts the domestic product when the so-called cross flexibility of demand described by K. Białecki indicates that increased purchase of imported goods causes smaller purchase of domestic goods ${ }^{26}$. Post-Fordist chains are also created by the so-called vertical integration, which is the idea designed by Toyota (and Toyotism as a variety of post-Fordism) 27 to include the subcontractor within the system of the final receiver of its goods in such a way that the former is both trained only to function in this particular system and that they are not able to move to another dominator. The concept of a world product is here an emphatic example of an organization of networks but also marketing control (Weberian Herrshaft together with Heglian Entfremdung) as well as in the sphere of the possibilities of creating innovations and new products, and even new domains that the buyer has not thought about, while their existence is possible. In other words, classes of subcontractors are isolated and they take a non-privileged position. They combine ruling in the media with persuasion by means of consumer tests in trade papers. It follows from my many-years' observations (confirmed by numerous scandals and recall campaigns) that, for example, German cars almost always win with others in the tests carried out by a car magazine Auto Bild of the Axel Springer concern (despite the commonly known scandals with TUV tests and "diesel" VW). The situation is the same with German tyres Continental, etc. However, it is difficult to catch the concerns red handed in such a delicate matter. Nevertheless, a certain idea on the range of links of the marketing machine in the form of the newspaper rankings with concerns can be given by the ADAC scandal. In 2014 it turned out that the second biggest car club in the world, which is German, framed the results of its annual competitions for the car of the year to the advantage of German producers ${ }^{28}$.

25 Poland Now.

26 K. Białecki, Marketing producenta i eksportera, Warszawa 1992.

27 A. Lipietz, Ideés fausses et questions ouvertes sur l'après-fordisme (conference materials), Lake Arrowhead 1991.

28 N. Goebel, Ch. Ignatzi, Outrage over data rigging at auto club, https://www.dw.com/en/outrageover-data-rigging-at-auto-club/a-17374687 (31.01.2021). 
Time-consuming areas such as agriculture function on local markets, in niches, "on the side". The character of capitalism, i.e. whether it is central or peripheral, is determined by the occurrence and size of the class of subcontractors. The countries called the traps of average income have the character of subcontractor countries. It is worth supporting this thesis with the data from which it follows that the majority of export of Central European countries is generated by the enterprises dependent on foreign countries so in fact on subcontractors. Only in 2016, 52\% of the Czech Republic's export was produced by Czech companies of foreign owners. An analogous index for Poland was 44\%, for Slovakia 75\% and for Romania $68 \%{ }^{29}$. It is from here that their relatively good position on markets comes from. Where there is only "developmental fringe" it is very hard to come out of social and economic backwardness. Dominators usually leave out-dated branches for the periphery where the post-Fordist modes of production are hard to realize (e.g. agriculture) and they subordinate to themselves those which have a big potential to create networks such as, for instance, trade or finances.

It is the networks and their integration as a reflection of domination which are the essence of post-Fordism. An example is the global product, which is usually finally assembled from the parts coming from various subcontractors in different countries integrated in a chain. The final assembly does not in this case give such a big advantage as in case of the brand production in the country of origin or the expansion of financial institutions. The advantage over subcontractors is ensured by the brands of trade networks (large stores or discount stores like, for example, Silvercrest in Lidl or Hykker for consumer electronics in Biedronka). They ensure domination and manage whole packages of transactions, sometimes creating new subcontractors (e.g. Auchan considerably increased the number of ponds with freshwater fish in Poland, providing fish from them to the whole network). They also decide on the nationality of the origin of products (e.g. Lidl prefers products of German producers, Żabka prefers the Polish ones). The strategy of a struggle for "all money from the market" and low prices is generally beneficial for the Polish subcontractors who have such commodities at their disposal. The advantage is revealed only when they organize competition in the network (e.g. for the services of mechanics and small shops trading with car parts, or products of the "home and garden" type, like in case of Nor-

29 M. Myant, Dependent capitalism and the middle-income trap in Europe na East Central Europe, https://content.sciendo.com/configurable/contentpage/journals $\$ 002$ fijme $\$ 002 f 54 \$ 002 f 400$ 2farticle-p291.xml (31.01.2021). 
auto and Leroy Merlin in shopping centers, Auchan, etc.) or when they have better ways of distribution (e.g. the Avon network marketing or the Internet auctions conquered by QXL company, the owner of Allegro portal). These changes define the process which I call the market vitality of capitalism, which has kept up for more than 250 years, while a lot of other work systems have collapsed and have even been absorbed by it.

Supplies and integration of suppliers is the domain of huge countriesexporters and the firms coming from them. Yecheckel Dror, in his report for the Club of Rome on "Global Governance" 30 shows the advantage of huge concerns over the states which are components of emergent markets. This concept also comprises the advantage of states-exporters which have dominated the world markets, and excessive profits from the brands generated by them. The present system of profit surplus is ensured by strong brands dominating in the areas frequently connected with car industry, petrochemical industry, trade and computer science. In Europe this is the casus of German firms and Germany as the state supporting its firms. Another example refers to Japan. Both these countries are large exporters and they do not have resources of raw materials but they make use of the resources of poorer countries which possess such resources. The situation is similar with American firms, which dominate especially in the area of both Americas, while in the fields of technique, information technologies and social media - in the whole world. This case refers to Apple, Toyota, VW-Audi plus Skoda and Seat, Sony, but also so-called chaebols from Korea such as Samsung, LG or Hyundai-Kia. The relation of domination-subordination in the present conjuncture, that is the present situation of capitalist economy, is the effect of post-Fordist dependencies affecting transformation and the appearance of successive economies on the world stage which try to imitate the success achieved, for example, by Japan. This model is successfully copied by both South Korea and China, or even Vietnam and Malaysia. On the other hand, the countries of southern and central America as well as African countries cannot succeed in it. Being a good subcontractor is frequently the way to imitate and build the position of dependent firms on the world market. It builds the consciousness of dependence in members of the working classes. Imitation is a fairly good way to leave peripherality; however, it should be creative imitation and creativity. The feature like entrepreneurship cannot be always easily formed among the economic representatives of nations dependent on the world centers. First, it is necessary to build

30 Y. Dror, Zdolność do rządzenia. Raport dla Klubu Rzymskiego, Białystok 2006, pp. 49-67. 
one's own so-called middle class, whose core are self-made entrepreneurs and their followers. In his theory of world-systems, Immanuel Wallerstein clearly presents the dependencies concerning the organization of the modes of production and work. Constructing the chain of dependencies usually first concerned the states which were closest to the center and their economies. The appearance of transnational firms created the epoch of globalization but it was not until China, as a huge country with its numerous firms - subcontractors, entered that the situation in the world changed. The chains of sub-supplies interlocked and some dominating countries were literally sucked out of the subcontractors of their own provenience, which means they gave away their production to the cheaper hands of peripheral countries. This especially concerns the USA or France, which was proved by the structure of social support for Trump within the frameworks of the presidential campaign and the main slogans of the rebellion of the so-called "yellow vests" against the French elite and against president Macron's rule. It needs to be noticed that lately the concept has appeared related to the class struggle for revindication due to those who performed tasks, the Webproletariat, that is Digital Workers (started by the protests of "Turkers" - workers of the Amazon platform Mechanical Turk directed to Jeff Bezos). French sociologists are contemplating the phenomenon of Uber, which created thousands of workplaces, mainly for young migrants who had but few other skills apart from driving vehicles and who are opposed by traditional taxi drivers who are losing the possibilities to earn money ${ }^{31}$.

A team of researchers from the Center for Eastern Studies explains the limitations of this model in the following way: "It can be noticed in certain areas that the political elites, especially in the Visegrad Group countries, are beginning to realize the negative consequences of the postFordist model and they try to place a certain dam for the expansion of foreign capital. Attempts are undertaken in Hungary and in Poland to limit the share of foreign capital in the financial sector and, in part, in the medical sector as well. In the Czech Republic, Slovakia or in Hungary limitations were placed on sales networks, thus making them increase the choice of local commodities"32. Especially in case of enterprises from Poland, the largest country within the Visegrad Group, attempts can be seen at leaving the model of dependent development and embarking

31 Le prolétariat du Web accède à la conscience de classe et lance sa première action collective pour améliorer ses conditions de travail (articles from "The Guardian" from December 2014), www.slate.fr (04.01.2020).

32 K. Popławski, Rola Europy Środkowej..., p. 59. 
on expansion on foreign markets, including those in the countries of a higher degree of development. Polish firms from the IT sector are taking over the competitors from Western countries and the size of foreign investments located abroad is going up. The famous takeovers concerned the producers of semi trailers: British Lawrence David, Italian Viberti, German Langendorf, or French Fruehauf SAS by the European largest producer in his area, i.e. the Polish Wielton from Wielun. This also refers to the expansion of the Polish concern Maspex in the food industry on the Central European market or Orlen in the fuel sector in the areas of the Cizech Republic and Hungary, but also in Lithuania and in Germany (565 petrol stations of the Star brand) ${ }^{33}$.

In conclusion, transaction, work and market in exchange for investment capital and foreign direct investment (FDI) create the class of subcontractors from dependent countries but this model of coming out of the periphery is not enough for the workers and elites of those countries. They question and openly contest it increasingly often. The danger, however, lies in whether after the Coronavirus crisis the fledgling firms of the SMBs sector will not be wiped out from the marker or simply bought by very wealthy competitors from corporations or taken over by China, which is the country with large financial surpluses and equally large aspirations, the last possibility being more and more loudly spoken about. The disappearance of the national middle class at home, which was created with such a big effort quite recently (at the beginning of the 1990's), and especially its breakup and exchange for hired employees of foreign companies may also be the process difficult to accept.

\section{Bibliography}

Althusser L., Ideologia i ideologiczne aparaty państwa, Warszawa 1983.

Bajoit G., Le changement social, Paris 2003.

Boudreault P.W., Du pouvoir et de l'entreprise dans une region post-industrielle. Le capital culturel et la ruse dans la création d'emploi, Chicoutimi 1994.

Bourdieu P., La distinction. Critique sociale du jugement, Paris 1979.

Dahl M., Niemiecki model społecznej gospodarki rynkowej jako wzór dla polskich przemian systemowych po 1989 roku, Warszawa 2015.

Domański H., Polska klasa średnia, Wrocław 2002.

Friedmann G., Le Travail en miettes, Paris 1964.

Galor Z., Bezrobocie a lumpenwłasność [in:] J. Tittenbrun (ed.), Własność $i$ interesy $w$ dobie transformacji, Poznań 2006.

33 https://www.orlen.pl/PL/OFirmie/OrlenWEuropie/Strony/OrlenWNiemczech.aspx (31.01.2021). 
Gardawski J., Zwiazki zawodowe na rozdrożu, Warszawa 2001.

Grosse T.G., Tragedia państw peryferyjnych, czyli o geopolitycznych dylematach Polski $w$ Unii Europejskiej, [in:] T. Zarycki (ed.), Polska jako peryferie, Warszawa 2016.

Lipietz A., Ideés fausses et questions ouvertes sur l'après-fordisme (conference materials), Lake Arrowhead 1991.

Myant M., Dependent capitalism and the middle-income trap in East Central Europe, https://content.sciendo.com/configurable/contentpage/journals $\$ 002$ fijme $\$ 002 f 54 \$ 002 \mathrm{f} 4 \$ 002 \mathrm{far}-$ ticle-p291.xml (31.01.2021).

Pareto V., Uczucia i działania. Fragmenty socjologiczne, Warszawa 1994.

Popławski K., Rola Europy Środkowej w gospodarce Niemiec, Warszawa 2016.

Popławski K., W pogoni za globalizacją. Niemieckie relacje z krajami BRIC, Warszawa 2013.

Popławski W.T., Popławski K., Szanse i pułapki post-fordyzmu w fazie "lean management" dla rozwoju państw peryferyjnych, [in:] W.T. Popławski, D. Kaczorowska-Spychalska (eds.), Nowe trendy $w$ zarządzaniu - wybrane uwarunkowania innowacyjności $i$ konkurencyjności, Łódź-Warszawa 2016.

Popławski W.T., Dylematy zbiorowej świadomości w obliczu „dryfowania” peryferyjnego państw. Esej o zmianie społecznej w państwach transformacyjnych, [in:] Z. Galor, R. Miński, P. Sałustowicz (eds.), Afirmacja czy kontestacja? Dylemat społeczeństwa kapitalistycznego w kryzysie, Bielefeld 2014.

Poulantzas N., Les classes sociales dans le capitalisme aujourd'hui, Paris 1974.

Sainsaulieu R., Lidentité du travail, Paris 1977.

Schmoller G. von, The Mercantile, System and its Historical Significance, London 1884, http:// ia800204.us.archive.org/3/items/mercantilesystem00 $\mathrm{schm} /$ mercantilesystem00 $\mathrm{schm}$. pdf (04.01.2021).

Staniszkis J., Postkomunizm. Próba opisu, Gdańsk 2005.

Stiglitz J., Wizja sprawiedliwej globalizacji. Propozycje usprawnien, Warszawa 2007.

Szacki J. (ed.), Ani ksiażę, ani kupiec: obywatel. Idea społeczeństwa obywatelskiego w myśli wspótczesnej, Warszawa 1983.

Weber M., Gospodarka i społeczeństwo, Warszawa 2002. 